\title{
Cradle-to-gate life cycle assessment of global manganese alloy production
}

\author{
Luke Aiden Westfall $^{1}$ (D) Julia Davourie $^{1} \cdot$ Mohammed Ali $^{1} \cdot$ Doreen McGough $^{2}$
}

Received: 6 May 2015 / Accepted: 30 October 2015 /Published online: 8 February 2016

(C) The Author(s) 2016. This article is published with open access at Springerlink.com

\begin{abstract}
Purpose Manganese is a metal used extensively in everyday life, particularly in structural steel. Despite the importance of manganese as an essential alloying element in steel and stainless steel, the environmental profile of manganese alloys lacked globally representative, primary industry data. The International Manganese Institute (IMnI) and Hatch completed the first global life cycle assessment (LCA) of manganese alloy production, providing environmental benchmarks and a firm foundation of accurate data with which to inform other industry-led initiatives.

Methods The study compiled primary data from 16 ore and alloy producers worldwide, covering $18 \%$ of global ore production and $8 \%$ of global alloy production for 2010 . This peer-reviewed, ISO 14040 compliant LCA covers the cradleto-gate life cycles of silicomanganese, ferromanganese, and refined ferromanganese. The study provides a comprehensive picture of global environmental performance, quantifying energy consumption, global warming potential (GWP), acidification potential (AP), photochemical ozone creation potential (POCP), primary water use, and primary waste generation. A novel model architecture was devised to generate process, site, and cradle-to-gate LCAs for single and multiple sites simultaneously, extracting greater value from the LCA process by facilitating environmental and operational benchmarking within the industry.
\end{abstract}

Responsible editor: Martin Baitz

Luke Aiden Westfall

lwestfall@hatch.ca

1 Hatch Ltd, 2800 Speakman Drive, L5K 2R7 Mississauga, ON, Canada

2 International Manganese Institute (IMnI), 17 Rue Duphot, 75001 Paris, France
Results and discussion The results of the study show that total GWP, AP, and POCP for $1 \mathrm{~kg}$ of average manganese alloy was $6.0 \mathrm{~kg} \mathrm{CO} 2 \mathrm{e}, 45 \mathrm{~g} \mathrm{SO}_{2} \mathrm{e}$, and $3 \mathrm{~g} \mathrm{C}_{2} \mathrm{H}_{4} \mathrm{e}$, respectively. Electricity demand and coal and coke consumption during smelting are the dominant operating parameters contributing to environmental performance. On-site air emission measures (GWP, POCP, $\mathrm{NO}_{\mathrm{X}}$, and particulate matter (PM)) contributed 25 to $35 \%$ of total life cycle emissions. Overburden and waste rock were the most significant primary solid waste flows by mass. The study provides a resource for improvement at the global industry and site scales by establishing benchmarks, identifying hotspots, and quantifying the benefits of efficiency savings through process optimization.

Conclusions This LCA provides accurate primary data to improve steel and stainless steel product LCAs and communicate the environmental performance of the industry in quantitative terms. It facilitates dialogue between manganese producers and consumers through a shared understanding of the environmental profile of the industry. Through leveraging the study to identify hotspots within the manganese supply chain, producers can work both independently and collectively towards improving the environmental and economic performance of manganese alloys.

Keywords Greenhouse gas emissions · LCA · Manganese • Mining $\cdot$ Smelting $\cdot$ Steel

\section{Introduction}

Manganese plays a critical supporting role in a variety of applications: as an essential nutrient for processing fats, carbohydrates, and protein; as a component of batteries, chemicals, and fertilizers; and as an alloying element in steel, aluminum, and copper production (IMnI 2015). Approximately 
$90 \%$ of total manganese production is in the form of highcarbon ferromanganese (HC FeMn), silicomanganese ( $\mathrm{SiMn}$ ), and refined ferromanganese (Ref. FeMn) alloys utilized in the production of steel and stainless steel for sulfur-fixing and deoxidizing and as an alloying element to improve strength and hardness (Olsen et al. 2007).

The manganese industry is global, with the majority of mining and smelting distributed between Asia, Africa, Australia, and Europe. In 2010, global manganese ore and alloy production was estimated at 44.1 and 15.8 million metric tons, respectively (USGS 2012). Previous life cycle assessment (LCA) studies available in life cycle inventory (LCI) datasets (Ecoinvent 2007; GaBi 2010) focus on the production of ferromanganese alloys by specific regions and producers. Despite the size of the industry and the critical role of manganese in downstream steel products, broader, global manganese alloy production has not been studied extensively using LCA.

The International Manganese Institute (IMnI) commissioned Hatch to conduct an LCA of global manganese alloy production to expand the knowledgebase of LCA, provide a more holistic view of the environmental impacts of manganese alloy production, and help drive environmental performance improvements within the industry. The study assembled primary data from 16 manganese ore and alloy producers across five continents into an independently peer-reviewed report compliant with ISO 14040 (2006a) and ISO 14044 (2006b) standards and available publicly at manganese.org (Hatch 2014).

This paper summarizes the goal, scope, methods, and results of the global manganese alloy LCA. Key findings of the study are presented for a variety of potential environmental impacts and indicators, and the contribution of each stage in the manganese supply chain are investigated. The sensitivity of the results to key parameters is also presented. Detailed information can be obtained from the full report online.

\section{Methods}

\subsection{System boundaries}

The LCA was a cradle-to-gate study spanning the extraction of manganese ore and manganese smelting in submerged electric arc furnaces and associated on-site and off-site processes including, but not limited to, grid electricity generation, fuel refining, coal mining, and cokemaking. The end-gate of the LCA is saleable lump manganese alloy, prior to distribution to iron and steelmaking facilities.

\subsection{Global industry representation}

The LCA covers 2010 production based on data collected from 16 mines and smelters. The site selection process aimed to capture a broad range of regional factors, facility sizes, production methods, and technologies. The LCA data and results are representative of global manganese ore and alloy production and cover production in Australia, China, France, India, South Africa, and the USA. The participating sites included in the LCA study represented $26 \%$ of global manganese extraction and $8 \%$ of global manganese alloy production in the study year.

\subsection{Functional units}

The LCA results are presented using four functional units to satisfy the internal industry and external communication objectives of the study (Table 1). The production of the three alloy systems represented by the LCA were modeled and reported independently to increase the value of the study as a tool for internal industry benchmarking and optimization. Data from each respective alloy system was represented relative to $1 \mathrm{~kg}$ of alloy of average compositions defined by the American Society for Testing and Materials (ASTM A99-03 (2009) and ASTM A483/A483M (2010)). An additional, fourth functional unit "average manganese alloy" was defined based on an average of the three alloy systems to provide results representative of the entire industry. The aggregated manganese alloy system contains an equal weighting of each production facility considered in the study, resulting in a 2:2:1 ratio between HC FeMn, SiMn, and Ref. FeMn, respectively.

\subsection{Life cycle impact assessment categories and environmental indicators}

The life cycle impact assessment (LCIA) considered the following potential environmental impact categories: global warming potential (GWP), acidification potential (AP), and photochemical ozone creation potential (POCP). The impact assessment was carried out using the CML 2001 mid-point method developed at the Institute of Environmental Sciences, Leiden University, Netherlands. In addition to the potential environmental impact categories, the LCA results highlighted a series of key process and environmental indicators. Table 2 summarizes the LCIA environmental impact categories and indicators presented in the results.

\subsection{Manganese alloy supply chain description}

The manganese supply chain was divided into modules representing primary (on-site) and associated upstream and downstream processes for each step of the manganese alloy production process (Fig. 1). Manganese ore is mined via conventional surface and underground mining methods. Surface mining involves the removal of overburden and blasting and extraction of ore and waste rock using primarily diesel-powered mobile equipment. Underground mines, in comparison, rely more on electricity and produce 
Table 1 Functional units

\begin{tabular}{lll}
\hline Functional unit & Designation & Description \\
\hline High-carbon ferromanganese & HC FeMn & $74-82 \mathrm{wt} \% \mathrm{Mn}$ and less than $7.5 \mathrm{wt} \% \mathrm{C}$ \\
Silicomanganese & SiMn & $65-68 \mathrm{wt} \% \mathrm{Mn}$ and less than 2.0 wt.\% C \\
Refined ferromanganese & Ref. FeMn & $80-85 \mathrm{wt} \% \mathrm{Mn}$ and less than 1.5 wt.\% C \\
Average manganese alloy & Avg. Mn alloy & $40 \% \mathrm{HC} \mathrm{FeMn}$ \\
& & $40 \% \mathrm{SiMn}$ \\
& $20 \%$ Ref. FeMn \\
\hline
\end{tabular}

less waste rock to selectively extract manganese ore. Ore is hauled by mobile equipment and conveyors from the point of extraction to ore processing and beneficiation plants, where run-of-mine (ROM) ore is crushed and separated from waste rock using crushers, wet screening, dense media separation drums, and cyclones. The waste rock from the processing plant is either stockpiled (dry) or sent to tailings impoundments (wet slurry). The manganese mining life cycle includes upstream diesel refining to power mobile equipment and on-site generators, electricity when connected to the grid, and the manufacture of tires to replace worn tires on mobile equipment.

Manganese ore fines and internally recycled manganesebearing fines can be agglomerated in sinter plants located at mining and/or smelting facilities. Sintering agglomerates fines and partially reduces manganese oxides in the ore using coal and coke. Sinter production requires upstream electricity, coal mining, and cokemaking. Emissions from sinter plants can be controlled using cyclones, scrubbers, baghouses, and electrostatic precipitators.

Manganese smelting occurs in submerged electric arc furnaces (EAFs), where electrical energy and coal and coke act to chemically reduce the manganese ore and sinter and produce metallic manganese in the form of molten HC FeMn and SiMn alloys. SiMn production involves the addition of a silicon-bearing material and often involves the recycling of slag generated during FeMn production. Manganese smelting is an energy and carbon-intensive process. Particulate emissions are controlled by baghouses and wet scrubbers. Slag waste generated from smelting is generally managed through internal recovery and utilization in by-product applications. Manganese alloy production involves a variety of auxiliary processes around the furnace, including slag processing, metal casting, crushing and screening, and raw material handling. The entire life cycle includes, but is not limited to, the production of upstream electricity, cokemaking, and coal, quartz, and limestone mining.

Refining of ferromanganese is performed in its molten state at oxygen converters following the furnace smelting stage. Refining reduces the carbon content of the alloy and produces MnO-rich dusts suitable for use in pigment manufacturing. The refining life cycle requires upstream electricity, oxygen, and a variety of other industrial gases.

\subsection{Life cycle modeling}

A customized modeling approach was devised to accommodate the multiple objectives and target audiences of the LCA by simultaneously developing LCA models at process, site, and global scales.

Each participating mine and smelter was modeled independently and later assembled with equal weighting to form the

Table 2 Impact and indicator categories

\begin{tabular}{|c|c|c|}
\hline Impact/indicator & Designation & Notes \\
\hline Global warming potential & GWP & Measure of greenhouse gas emissions \\
\hline Acidification potential & $\mathrm{AP}$ & Measure of acid rain-generating emissions \\
\hline $\begin{array}{l}\text { Photochemical ozone creation } \\
\text { potential }\end{array}$ & POCP & Measure of smog-forming emissions \\
\hline Nitrogen oxides & $\mathrm{NO}_{\mathrm{X}}$ & Emissions of controlled and fugitive nitrogen oxides to air \\
\hline Sulfur oxides & $\mathrm{SO}_{\mathrm{X}}$ & Emissions of controlled and fugitive sulfur oxides to air \\
\hline Particulate matter & $\mathrm{PM}$ & Emissions of controlled and fugitive particulate matter to air \\
\hline Comprehensive energy demand & CED & $\begin{array}{l}\text { Total raw energy inputs associated with manganese production, including upstream and downstream } \\
\text { processes }\end{array}$ \\
\hline Primary energy demand & PED & Energy delivered to primary manganese production processes only \\
\hline Primary water consumption & Water & Water consumption by primary, on-site manganese processes only \\
\hline Primary waste generation & Waste & Waste generated by primary, on-site manganese processes only \\
\hline
\end{tabular}




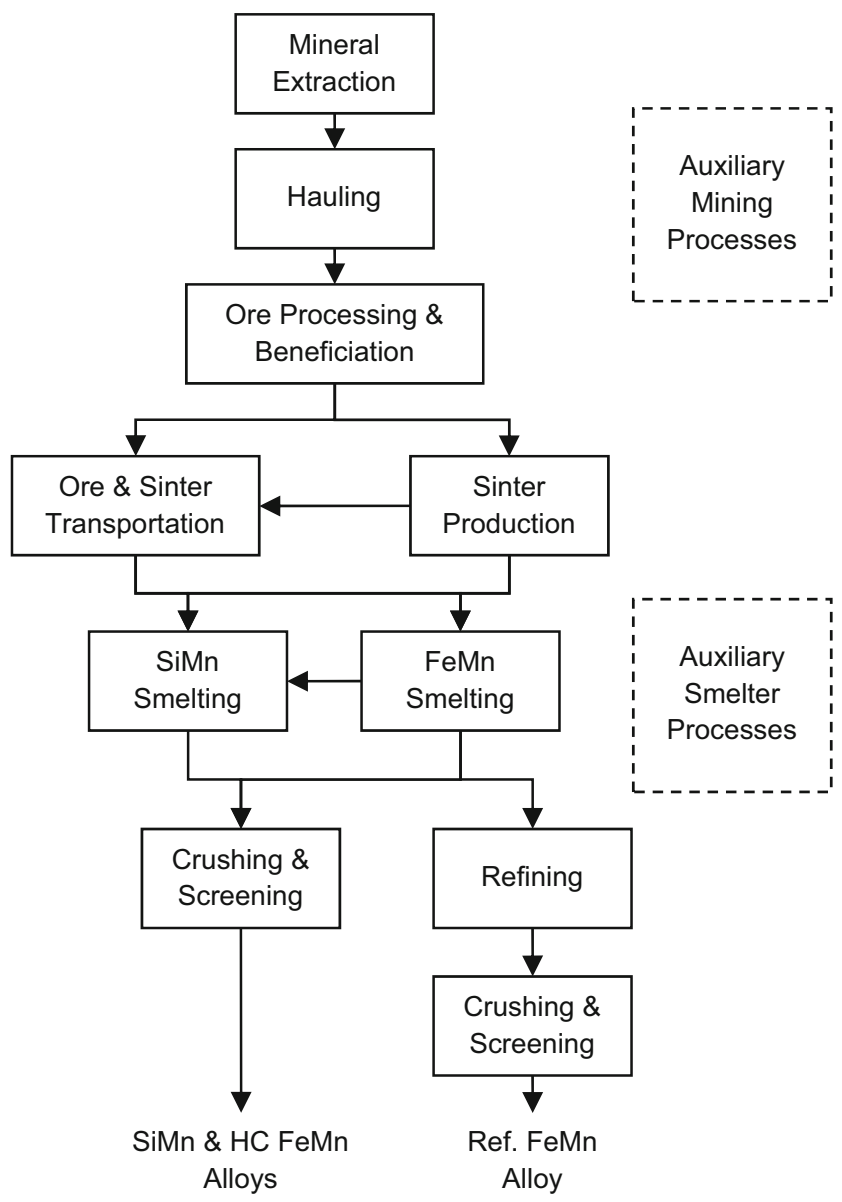

Fig. 1 High-level model schematic illustrating separate sets of mines, sinter plants, and alloys used to build up to the global LCA model

complete global system. Each site model was composed of common process modules to allow for the comparison of individual processes across multiple sites for site benchmarking and data validation purposes. Individual site models were compared to industry averages in confidential site-specific reports to help drive optimization within each participating facility.

Primary site data was collected by site visit and data questionnaire and formed the flows into, out of, and within the primary manganese supply chain. Secondary upstream and downstream processes were linked to the primary material flows using Ecoinvent and GaBi LCI datasets and modeled using GaBi Life Cycle Engineering software. Region-specific LCI data was used to reflect differing electricity grid mixes in each participating country.

The life cycle models for each site were added to form the global models representing each manganese alloy system. Each alloy system was then summed to form the global average manganese alloy system, resulting in a 2:2:1 ratio between HC FeMn, SiMn, and Ref. FeMn, respectively. This ratio is reflective of the representation of participating facilities, and in comparison to global industry production, is over-weighted, under-weighted, and balanced for HC FeMn, SiMn, and Ref. FeMn, respectively.

\subsection{Allocation and co-products}

A number of co-products result from manganese alloy production and leave the primary manganese supply chain. Noteworthy co-products include slag produced during smelting and $\mathrm{MnO}$ dusts collected from the refinery off-gas stream. Slag is often used as an aggregate material for local construction, diverting a waste stream but receiving no allocation of environmental impacts. However, FeMn slag can be an important manganese-bearing material for SiMn production, and a mass allocation is used to transfer a portion of the environmental burden of FeMn furnaces to slag destined for SiMn production. $\mathrm{MnO}$ dusts are typically sold as a valuable pigment, although no allocation is allotted due to the small quantity of $\mathrm{MnO}$ produced, which yields proportionally low economic value compared to alloy production.

\section{Results}

Cradle-to-gate potential environmental impacts and indicators are presented in Table 3 for each manganese alloy type. Each metric covers upstream and downstream activities with the exception of primary energy demand, water consumption, and waste generation which, by definition, pertain to the primary manganese supply chain only. Figure 2 shows the contribution of primary and indirect processes to the total life cycle results.

An examination of the contribution by each stage along the primary manganese alloy production process is shown in Fig. 3. The breakdown by process incorporates the upstream and downstream indirect processes associated with each primary process stage segment. The results show a profile consistent with carbon and energy-intensive processes. Greenhouse gas emissions, combustion-derived air emissions, and energy consumption are particularly driven by upstream power generation and primary consumption of coal and coke associated with the electricity and carbon requirements of the furnace smelting process.

The contribution of mining to environmental impacts is connected to the handling of raw materials, which requires process water, produces fugitive PM emissions, and is responsible for $99 \%$ of waste generated (by mass) from primary manganese processes. Waste from manganese mines includes inert waste rock, overburden, and tailings, which are managed locally at the mine. While mining relies on diesel-powered mobile equipment and generators, its contribution to total life cycle emissions is relatively small compared to the smelting process. 
Table 3 Environmental impact and indicator results for each manganese alloy ${ }^{\mathrm{a}}$

\begin{tabular}{lllll}
\hline & Avg. Mn alloy & SiMn & HC FeMn & Ref. FeMn \\
\hline GWP $(\mathrm{kg})$ & 6.03 & 6.94 & 5.06 & 6.18 \\
$\mathrm{AP}(\mathrm{g})$ & 45.0 & 52.4 & 35.4 & 49.6 \\
$\mathrm{POCP}(\mathrm{g})$ & 3.03 & 3.33 & 2.47 & 3.55 \\
$\mathrm{NO}_{\mathrm{x}}(\mathrm{g})$ & 18.7 & 20.1 & 15.5 & 22.4 \\
$\mathrm{SO}_{\mathrm{x}}(\mathrm{g})$ & 30.9 & 37.5 & 23.9 & 31.5 \\
$\mathrm{PM}(\mathrm{g})$ & 9.58 & 11.50 & 8.47 & 7.96 \\
$\mathrm{CED}(\mathrm{MJ})$ & 73.4 & 86.1 & 63.2 & 68.4 \\
$\mathrm{PED}(\mathrm{MJ})$ & 35.6 & 39.6 & 31.9 & 34.9 \\
Water $(\mathrm{kg})$ & 11.3 & 12.9 & 8.8 & 13.0 \\
Waste $(\mathrm{kg})$ & 26.5 & 21.9 & 29.2 & 30.3 \\
\hline
\end{tabular}

${ }^{\text {a }}$ All figures relative to $1 \mathrm{~kg}$ of manganese alloy product

Additional detail and results are available in the complete peer-reviewed LCA report available at manganese.org (Hatch 2014).

\section{Discussion}

\subsection{Influence of electricity generation}

Electricity generation plays the most critical role in the life cycle of manganese alloy production. Figure 4 shows the total contribution of on-site and grid-sourced electricity on the manganese life cycle. The significance of electricity generation on environmental performance is due to the electricityintensive smelting process coupled with coal-intensive electricity grids operating in the majority of manganese alloy-

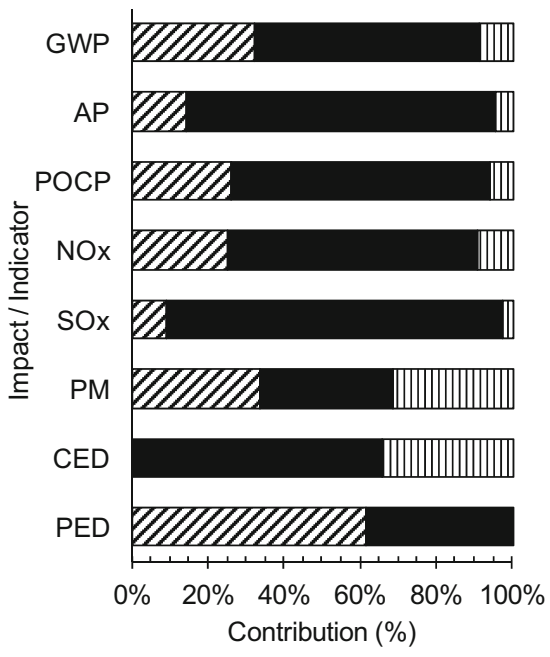

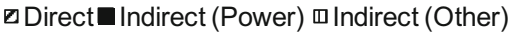

Fig. 2 Contribution of direct and indirect processes to total life cycle environmental impact and indicator results for average manganese alloy production

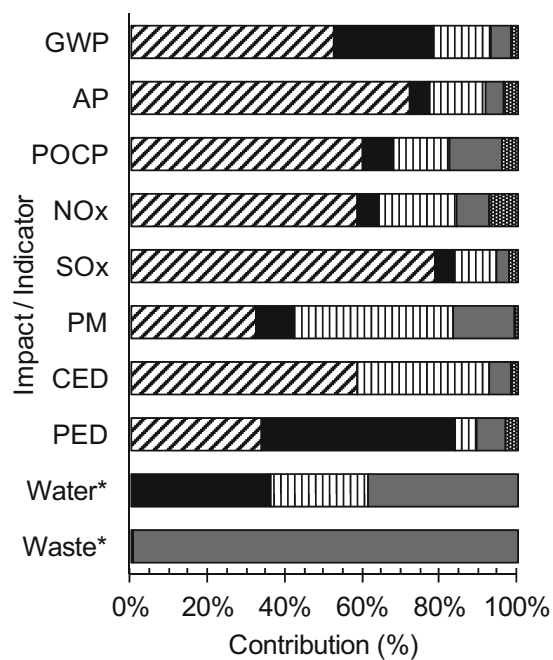

$$
\begin{aligned}
& \text { चFurnace (Electricity) aFurnace (Direct) } \\
& \text { ๓Smelter (Other) aMining \& Sintering } \\
& \text { 面 Transport } \\
& \text { * Primary water consumption and waste } \\
& \text { generation, excluding off-site processes. }
\end{aligned}
$$

Fig. 3 Breakdown of environmental impacts and indicator results by process stage groups for average manganese alloy production

producing countries considered in the study. While current methods of producing manganese alloys necessitate a source of carbon for the reduction of manganese oxides, a variety of technology options are available which could significantly lower the fossil fuel requirements of electricity generation in manganese-producing countries.

The results of a sensitivity analysis investigating the influence of upstream electricity production mixes are shown in Fig. 5. The analysis compared the LCA results for average manganese alloy production based on the least and most carbon-intensive grids included in the study. The results show

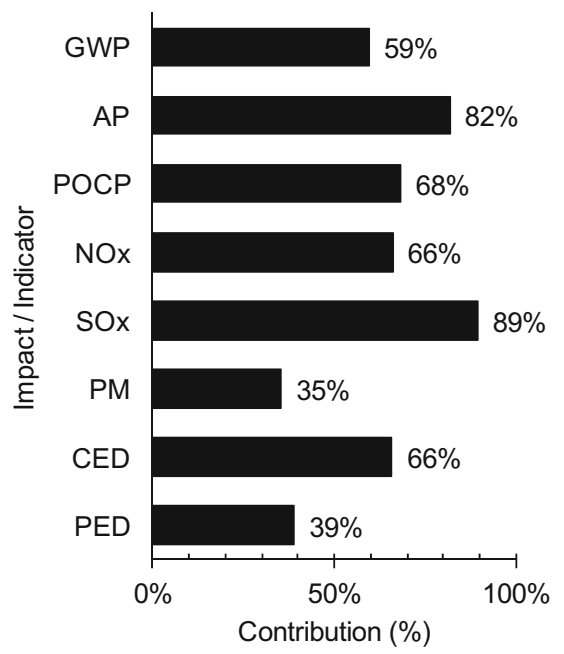

Fig. 4 Contribution of on-site and grid-sourced electricity generation on total environmental impacts and indicators for average manganese alloy production 


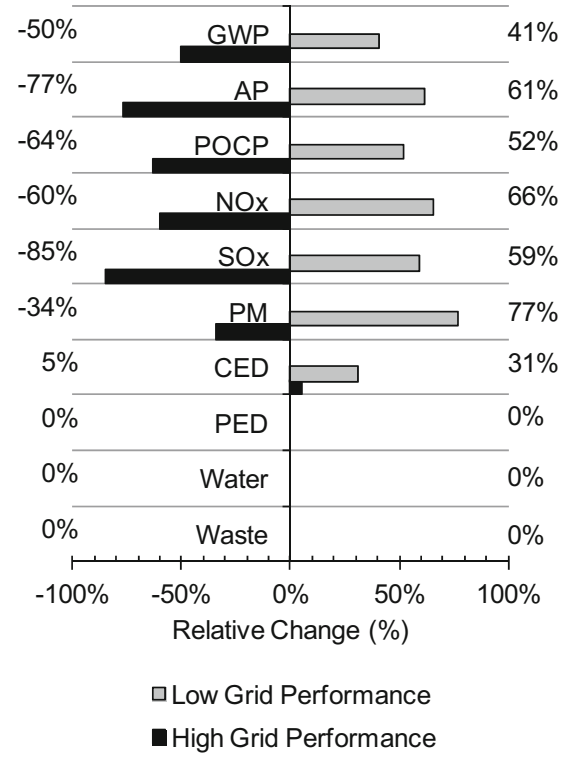

Fig. 5 Sensitivity analysis results showing the influence of low- and high-emission electricity production on total life cycle environmental impact and indicator results for average manganese alloy production

a large disparity between smelters based on their regional grids and highlights the significant improvement in the manganese life cycle that could be achieved through transforming electricity production from coal-based to more low-carbon and low-emission alternatives. Without changes to electricity production, manganese smelters with closed furnace systems can reduce reliance on grid electricity by on-site recovery of $\mathrm{CO}$ off-gas for electricity generation and waste heat utilization.

\subsection{Smelter waste generation and diversion}

Smelters generate large quantities of slag as a result of manganese alloy production. A variety of practices are followed for managing, utilizing, and reducing the amount of waste generated from manganese slags. Figure 6 shows

Fig. 7 Empirical relationships between the range of participating manganese ore and alloy producers showing a diesel consumption for mineral extraction and hauling versus total material hauled; $\mathbf{b}$ primary energy delivered to SiMn and FeMn furnaces as a function of total ore and sinter charge; and $\mathbf{c}$ the mass of carbon versus manganese and silicon content charged to SiMn and FeMn furnaces (a)

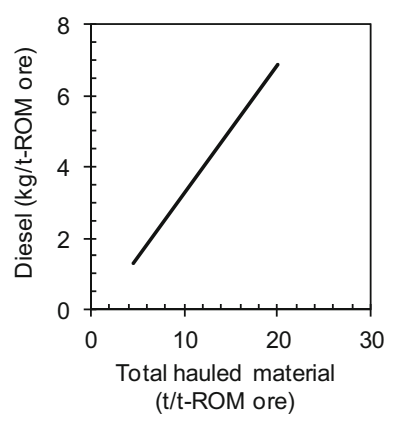

$R^{2}=0.96$ $m=0.36 \mathrm{~kg} / \mathrm{t}$

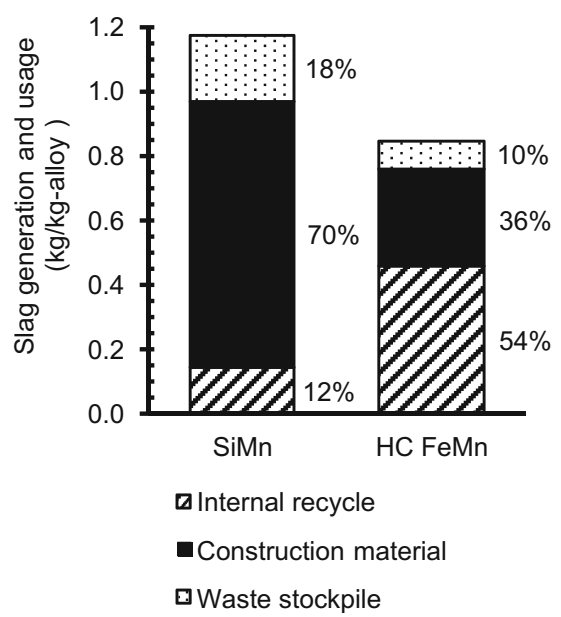

Fig. 6 Average slag generation relative to SiMn and HC FeMn alloy production showing end-use applications of slag; 82 and $90 \%$ of slag produced is utilized as a by-product of SiMn and HC FeMn alloy production, respectively

the amount of slag generated by SiMn and HC FeMn production and the associated end-use applications of manganese slags. The highest value application of manganese slags is in recovery of manganese-bearing materials entrained in the slag. The majority of HC FeMn slag generated is recycled during SiMn smelting to recover its manganese content. A significant portion of slag is also utilized in the construction industry for its physical properties as an aggregate material. Combined, 82 and $90 \%$ of all SiMn and HC FeMn slag generated by the manganese life cycle are diverted from what would otherwise be a significant waste stream for manganese smelters. Utilization of slag in construction is influenced by the classification of slag as a hazardous or non-hazardous material and by local demand. Further utilization of slag can assist in reducing the upstream impacts of the extraction and processing of additional units of manganese and the downstream impacts of stockpiling and managing waste.

(b)

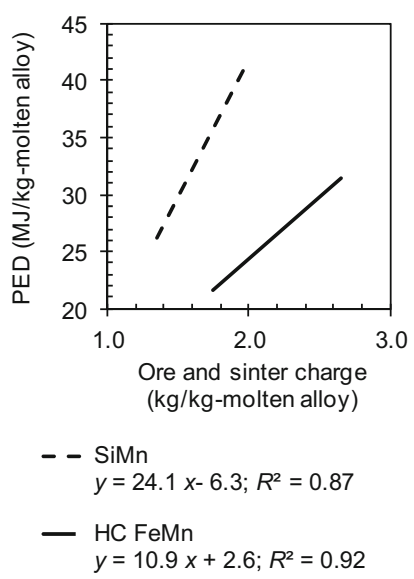

(c)

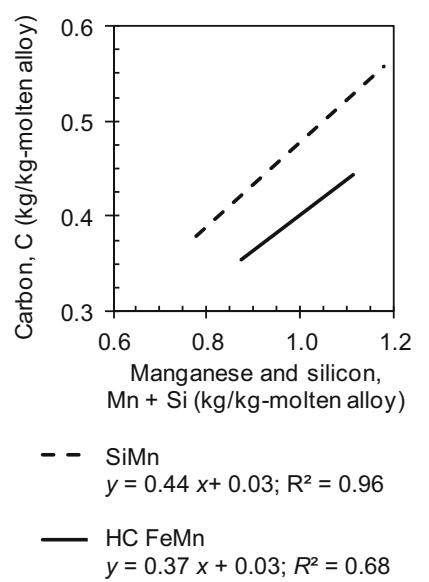




\subsection{Key process consumables and relationships}

Independent modeling of individual mining and smelting operations using standardized process module definitions enabled analyses of various relationships between key process consumables driving environmental performance and the underlying operating parameters governing manganese production. Figure 7 presents a selection of empirical trends observed across the range of manganese production facilities included in the study. The range of diesel consumed across mine sites during mineral extraction is linearly proportional to the total mass of ore, overburden, and waste material hauled. As a result, mines with high stripping ratios and/or high ROM ore-to-product-ore ratios generally require more diesel and generate more emissions than do other mines. During SiMn and HC FeMn smelting, the energy and carbon charged to the furnace is related to the charge of manganese and siliconbearing materials. Primary energy demand, in the form of electricity, coal, and coke, increase with the proportion of mass charged to the furnace in order to reach and maintain required reaction temperatures. As a result, low-grade ore and sinter inputs act to increase the energy requirements of the furnace by carrying a higher portion of non-metallics in the total furnace charge. Comparing the elemental balance between the carbon content in reducing agents and manganese and silicon content in the charge of ore, sinter, and siliconbearing materials shows that the carbon charge is regulated by producers to meet the chemical requirements of the reduction reaction, while the energy burden of non-metallics in the furnace is met by increasing electricity consumption. As the dominant contributors to total environmental performance, optimizing furnace electricity and carbon requirements through selection of charge materials could reduce furnacerelated life cycle impacts.

\section{Conclusions}

The manganese alloy LCA project provides globally representative primary industry data to better understand the environmental performance of HC FeMn, SiMn, and Ref. FeMn alloys used in steel production. The study improves the regional breadth and number of alloy systems considered by previous LCA work in this area by including primary data-based models of 16 manganese ore and alloy producers. Customized modeling approaches were applied to increase the relevance of the LCA results for driving internal industry optimization to satisfy both internal and external industry objectives.

The results of the study show that manganese alloy production is an energy- and carbon-intensive process, whose overall environmental performance is closely tied to the environmental performance of regional grid electricity production. By linking environmental results of process consumables and operating parameters, LCA data and methods can be integrated into traditional cost and process optimization. Links between operating parameters and environmental impacts can support strategy, decision-making, and simultaneous enhancement of economic and environmental performance within the industry.

Acknowledgments The global manganese alloy LCA project was conducted by Hatch with oversight and funding provided by the International Manganese Institute. The authors recognize the voluntary, in-kind contributions and provision of primary industry data by the manganese producers participating in the study, including Assmang Ltd; BHP Billiton Ltd; CITIC Dameng Mining Industries Ltd; Comilog SA; Consolidated Minerals Ltd; Eramet Comilog Manganese; Eramet Marietta Inc.; Glencore plc; Guangxi Xin Manganese Group Co., Ltd; Jiaocheng Yiwang Ferroalloy Co., Ltd; MOIL, Ltd; OM Manganese Ltd; Sarda Energy \& Minerals Ltd; and Tata Steel Ltd Ferro Alloys \& Minerals Division. The LCA conforms to ISO 14040 and ISO 14044 standards. The critical, independent third party review was conducted by Dr. Tom Gloria (Chair), Managing Director, Industrial Ecology Consultants; Dr. Steven Young, Associate Professor, University of Waterloo; and Dr. Johannes Gediga, Global Sector Lead Mining Metals and Manufacturing, PE International AG.

Open Access This article is distributed under the terms of the Creative Commons Attribution 4.0 International License (http:// creativecommons.org/licenses/by/4.0/), which permits unrestricted use, distribution, and reproduction in any medium, provided you give appropriate credit to the original author(s) and the source, provide a link to the Creative Commons license, and indicate if changes were made.

\section{References}

ASTM Standard A99 1999 (2009) Standard specification for ferromanganese. ASTM International, West Conchohocken

ASTM Standard A483/A483M 2010 (2010) Standard specification for silicomanganese. ASTM International, West Conchohocken

Ecoinvent Centre (2007) Ecoinvent data v.2.0 ecoinvent reports No. 125. Swiss Centre for Life Cycle Inventories, Dubendorf

Hatch (2014) Lifecycle assessment of global manganese alloy production. International Manganese Institute, Paris, Available online: http://www.manganese.org

International Manganese Institute (IMnI) (2015) About Manganese. http://www.manganese.org/about-mn. Accessed 10 Mar 2015

ISO (2006a) ISO 14040:2006 - Environmental management - Life cycle assessment - Principles and framework. International Organization for Standardization, Geneva

ISO (2006b) ISO 14044:2006 - Environmental management - Life cycle assessment - Requirements and guidelines. International Organization for Standardization, Geneva

National Minerals Information Center, U.S. Geological Survey (USGS) (2012) U.S. geological survey minerals yearbook - manganese 2012. U.S. Government Printing Office for Minerals Yearbook, Reston

Olsen S, Tangstad M, Lindstad T (2007) Production of manganese ferroalloys. Tapir Academic Press, Norway

PE International (2010) GaBi4@ Lifecycle Engineering Software 